\title{
The Study Expectations and Perception Marine Sports Tourists in the Aqaba Special Economic Zone
}

\author{
Ibrahim Mohammad Abujamous \\ Faculty of Engineering Technology, Al Balqa Applied University
}

\begin{abstract}
The aim of this study to know the level of quality expected and the level of the perceived quality of the marine sports tourists in Aqaba special economic, identify gaps between both and compared each dimension of quality of service. The selection of an appropriate sample consisting of 300 directed them to form search through the distributed to tourists Royal Marine Sports Federation and 240 questioner forms of tourists and valid for analysis. Servqual scale was also used to measure the gap between the expectations of the tourists from the quality of the service before their use and understanding after obtained through the five dimensions of the Servqual of the quality of the service.As the use of statistical methods descriptive normative Standart divination, duplicates, and ratios to describe the characteristics of the sample respondents answer the dimensions of quality, and also use the link and decadence and contrast test-t, test-f to analyze the results of the study and test the hypotheses. The study found that the difference between the average and the average expectations perception was negative for each dimension of quality, which indicates that the level of perceived quality after receiving the service is less than the level of quality expected before receiving service and all dimensions, which means that the management of the Jordanian Royal Marine Sports Federation work to improve the level of services provided to tourists in every dimension of the quality of the service in order to exceed the expectations of tourists or equally.
\end{abstract}

Keywords: Quality, Marine Sports, Expectation, Perciption, the Aqaba Special Economic Zone, Royal Marine Sports Federation.

DOI: $10.7176 / \mathrm{JTHS} / 45-04$

Publication date: December $31^{\text {st }} 2019$

\section{Intorduction}

The world is currently affected by multiple variables in the political, economic, social, technical and competitive and informatics, a result of globalization and the information technology and communications technology and technological, which facilitated the movement of goods and services easily between all countries of the world, if it is still possible government intervention, even on a limited basis in the area of movement of goods, this may become impossible in regards to services. From here, a lot of organizations, including the marine sports establishments and information centers seek to upgrade the level of services, even to the degree of excellence; where those institutions used a number of strategies to develop and improve the level of performance, and between these strategies for improving the quality of being help to provide appropriate services to meet the needs of current and prospective clients and phenomenon, since libraries Obstetrics is one of the important service institutions which seek to provide a unique service and distinct and different from the rest of the types of institutions and other service, so the quality is supposed to be one of the most important areas of interest to the department in the library, as is the case in any production facility seeks to increase and improve the level of proficiency of their products and services(Abu Rumman et al,2013; Alananzeh et al,2018; Al-Hussein et al,2015).

The Jordan Olympic Committee (JOC) is the governing body for sports in the Hashemite Kingdom of Jordan. Founded in 1957, the JOC became the nurturing body for 34 Olympic and non-Olympic sports federations in the kingdom, laying down the foundation and trail to develop and rise up with the state of sports in Jordan. The Jordan Olympic Committee (JOC) is a non-profit organization that represents the strong, independent voice for Jordanian Olympic Sport and the place for all aspiring athletes to better themselves and grow while representing Jordan all around the world.

Perceived Quality is the imprint of fineness that client knowledges about a product, brand or business, derived through sight, sound, touch, and scent.

It is the customer's perception of a produce's reliability and heftiness, the impression of care and craftsmanship invested in its manufacture, the sense of richness and strength of the materials used, the evident fine attention to detail, and the feeling of the depth of engineering behind the design (ALsarayreh et al,2011; AlShawagfih et al,2015; Amyan and Jawabreh,2011; Bazazo et al,2017; Jawabreh,2014a).

This is quite separate from actual reliability and robustness, attributes that are vital for a product to be competitive, but not characteristics that will distinguish it as special, or propel it into the "premium" segment.

In a world where consumers are increasingly being offered functional, reliable, feature laden products, smart businesses are focusing on perceived quality to transform functionally competitive products into more desirable, premium products, for which higher prices can be commanded.

The individual act in a certain manner because there is prompted by the choice of the defended certain 
behavior without other behaviors, because the result is expected to be obtained from this behavior, the essence of the theory is that the motive to select a specific behavior to be determined by the desire of the result. But there is essential in this theory is the process of how to treat the individual with catalytic, before making the final option. The result is not the sole determining factor in deciding how to act Oliver, R. (August, 1974), focusing on the mental processes theory expectation with regard to the choice or options. It explains the operations of the individual to determine the options. Motivation that control process options from among alternatives to voluntary activities, a process governed by individuals. Identify the individual and his choices based on the assessment of the extent to which the expected results of a specific behavior of the desired results. The motivation or incentive is the product of the individual expected that a particular effort will lead to performance required; this is defined as the use of performance to achieve a particular result and the desire( Jawabreh and Al Sarayreh,2017; Jawabreh et al,2015)

Jordan has witnessed a significant development in the field of hospitality industry in shaping, and this research will identify the level of quality of service in the Royal Marine Sports Federation how aware of the customer and what factors affect the evaluation of those services. The proportion of investment in tourism in the tourist restaurants in Jordan, including approximately (15\%) to reach about 211 million dinars and annual income by $33 \%$ ( Jawabreh et al,2017).

The tourism sector in the Kingdom of important tourist sectors, where $13 \%$ of GDP which contributes to the national economy and the labor force survey results showed airplane and departing for the period 2016/2017, tourism income earned from tourism amounted to about 3,216 million dinars and the number of total arrivals to Jordan 6.78 Color people, the number of arrivals residing in Jordan about 1.8 million visitors(Jawabreh, 2017b)

The Union was founded in the Jordanian royal marine sports in Aqaba at the end of the 1960s and was called the Union of water sports and is now one of the official sports federations of the Jordanian Olympic committee under the Jordanian sports federations No. (87) for the year 2004 and issued under article (9) of the Jordanian Olympic Committee Law No. (66) For the year 2001. It is the only sports federation based outside of the capital Amman and is located in the city of Aqaba, where the sports union is freely in the first instance this is the reason that created the union's headquarters in the coastal city of Al Aqaba to practice these marine sports

And for that it has conducted this study to achieve a set of goals, to know the level of quality expected by tourists, and knowledge of the perceived quality level by tourists. Also identify gaps between the level of quality expected-directional by tourists compared with the level of quality expected-directional for each dimension of the quality of service and finally to know the extent of the impact of the demographic characteristics of the beneficiary of the level of quality expected Perceived.

\section{The research problem:}

Identify the level of quality of services in the Royal Marine Sports Federation from the point of view of clients aimed at seeking the strengths and shortcomings, and to develop, the principal هو الضمان upgrading them, and gain the satisfaction and loyalty of tourists. The question here is:

What is the assessment of the clients of the restaurant and the quality of the service provided to them?

Under this question, the following subsidiary questions:

1 -What is the quality expected-directional by the beneficiaries of the services provided?

2-Is there a statistically significant differences between the quality expected perceived quality attributed to keep quality as measured by Servqual?

3. Is there statistically significant differences in the perceived quality of demographic factors attributable to the beneficiaries?

4. What do we mean by the quality of service?

5-What are the criteria upon which the tourists in their assessment of the quality of the service provided to them? 6-Is there a statistically significant relation between the criteria of quality of service and satisfied with tourists and the overall quality of the service provided?

7-Is there a statistically significant relation between each of the criteria of quality of service and satisfied with tourists and the overall quality of the service provided? 


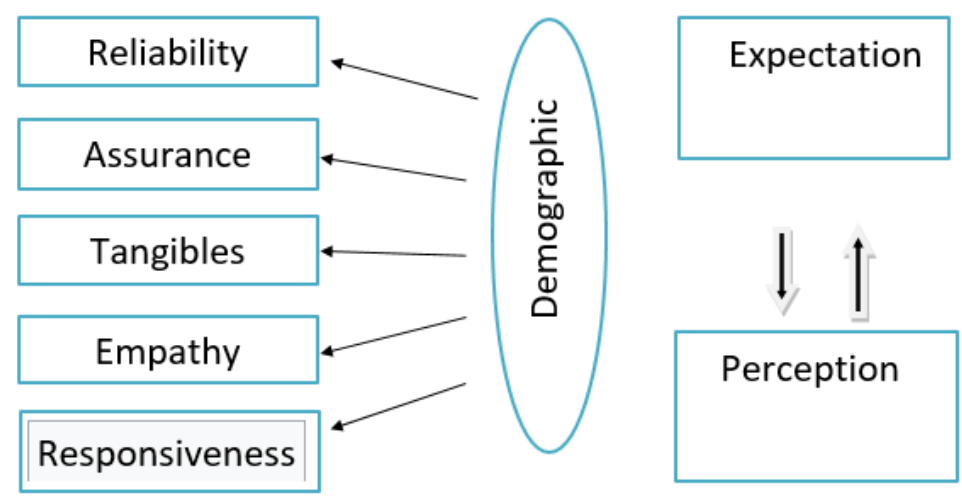

Figure 1. The study model

\section{Previous studies}

Expectations of service quality Servqual scale is used on all directions of the beneficiaries about the actual performance of the service provided to them, and the application of the Libraries and Information Centers, Servqual the specialized agencies, the study has confirmed the credibility of the measure, despite some reservations about some of the points contained therein.

study Qdadeh, 2009 ) on the quality of educational services in the Jordanian universities, to identify the various dimensions of the model of the quality of the educational services expected affecting the educational services and the satisfaction of the student, which includes four elements: due diligence, reliability and responsiveness.

Quality is important topics and vitality which increased attention, especially in the last period, with increased competition in the local, regional and international levels, so that restaurants, hotels, and is interested in upgrading the quality of their products and services, in order to protect itself in light of the stiff competition so that they can reach the level of quality and achieve tangible success in the field of global competition for the products of high quality and low cost, which the final consumer prices. As quality is the biggest advantage of the service provided and strong competitive service organizations in general.

The management of the services sector should focus on improving the quality of its services on a continuous basis, commensurate with the needs and requirements of its clients and responds to the wishes of its employees, which helps to increase productivity and increase profits and improve its reputation in the local and global market, which increases the chances of success in the work environment competition clients beneficiaries are those who are granted life and continuity of the organization through the turnout to obtain services or goods provided by the Organization.

The issue of quality researchers in their studies discussed from more than one angle, more from the perspective, this led to the diversity and definitions of this concept. It is months quality definitions is the definition of the American Society for Quality referred to by researchers (Adrian et al,2011; Anne-Mette,2001)quality is the overall characteristics of the product or service a commodity that appear and reflect the ability of this product to satisfy the needs of the Explicit and implicit explicit Implicit.

The quality of service from the point of view of researchers ( Chris et al,2016; Cong and Dam,2017) the degree of satisfaction that can be achieved by the service to beneficiaries and tourists through the satisfaction and to meet their needs, desires, and expectations.

Quality of Service can be defined from the perspective of the service provider and the perspective of the beneficiary of this service, and this is emphasized by the two researchers (Crystal and Cristina,2016) quality from the perspective of the service provider is identical to the service standards set in advance of the service, the quality of service from the perspective of the beneficiary, the client is the harmonization of this service.

The researcher sees Dongfeng,2016 that quality of service is the degree of preference at an acceptable price, and controls the variables costs of acceptable. The researcher 1002 quality to reflect the concept just mean different things to different persons, quality reflect the degree of brilliance and excellence and the fact that the excellent performance and the fact that the characteristics or some of the characteristics of the product (service or product) is excellent when compared with standards set from the perspective of the institution or from the perspective of the beneficiary) of the customer.

The researcher Bank believes that quality is the ability of the Product (a service or a commodity) to achieve the full satisfaction of the needs and desires of the beneficiary, the client least internal costs.

The researcher knows Evans quality as to meet and satisfy the expectations of the beneficiary, the customer or provide more than these expectations. The researcher sees Mitra that quality reflects the capacity of the product (service or a commodity) to harmonize the use as requested by the beneficiary, the wishes of the customer. 
The researcher confirms that quality reflect the avoid and avoiding the loss caused by the Product (service or product) the society after submission for use, this includes losses arising from the failure to meet and satisfy the expectations of the beneficiary, the client and the failure to meet the performance characteristics and the negative side effects that result from the product, such as the pollution of the environment.

Also known Donald,2005of the quality of service through the three dimensions of services in his book marketing services technical dimension of which consists in the application of science and technology of a certain problem career dimension any way in which the process of the transfer of the technical quality to the client and represent such interaction. The psychological and social between the provider and the client that uses the service. The material which is the place in which the service.

The quality of service and great importance for institutions designed to achieve success and stability, in the area of commodity products planning can be used in production, and the Classification of Products waiting for customers but services, customers and employees who work together to create a service delivery at the highest level, the attention of staff and tourists together institutions

SERVQUAL appeared during the 1981 through studies by parasuraman, Zeilhmal et berryin order to be used in the documentation and examination of the sources of quality difficulties and assistance in how to improve the quality valuation as a model the gap means determining the gap between customer expectations and the level of service and understanding of the actual performance. Any knowledge and to determine the extent of congruence between the expected service perceived service berry and his colleagues have reached in 1985 through studies that the main focus in the assessment of the quality of the service according to this model is the gap between the customer's understanding of the actual level of performance and expectations of the service and this gap depends on the nature of the gaps associated with the design and marketing of service delivery. The construction of this model depends on identifying the steps that must be taken into account when analysing, planning, quality of service,

There are four steps are essential to achieving quality as input to achieve quality and are: the analysis of the expectations of the tourists, a description of the quality of service, improves staff performance, and managing the expectations of the tourists (Girish et al,2017)

And pointed out that there are six stages to deepen the concept of internal quality assurance in service organizations and are: to create awareness of the importance of internal quality assurance, work to create uniformity and comparability between the front and rear lines, the efficiency of internal communications, ongoing customer satisfaction measurement procedure, improving the efficiency of the feedback for the continued development of the work, and necessary adjustments in action whenever needed, while others pointed to the importance of the gaps in quality of service (Grzegorz and Thomas,2017; Ho et al,2016; Jiaying et al,2017).

And a study indicated that the dissatisfaction of the Working Group will only lead to non- interactions with the customer, he stressed that attention must be paid to employees in the front lines because they are in constant contact with tourists, through them and interest them can organi to promises you made and the requirement of topped itself as well as the role played by the workers in me topped customer expectations and those expectations to be services expectations and aspirations, as well as help them topped how to use many of the counselling services and advice. Securing the dimensions of depends largely topped the ability and skill in me restaurant workers improve their customer been cleared so that them to services through interaction and communication successful working condition that has services me deal, and self-reliance (Mohinder, 2010).

The objective Management Services is in me to ensure that consistent and coordinated to provide quality services not and can achieve this consistency and harmony through standards has been developed by the evolution of restaurants managed in an orderly border thought makes what is taught and desired level of performance $(\mathrm{J}$. Lucy et al,2018; Joan et al,2010).

The expectation effective and appropriate to require that the Service at least on the needs of the client, it must provide services and provided to the customer before requested by himself (Klaus,2000; Lan-Lan et al,2014).

And there is a study on the quality of services and performance of workers in the public sector and specifically the offices of the immigration and passports in Malaysia, and adopted the measure of SERVALQUAL study the quality of the services, which consists of all the dimensions of quality, and the results of the study showed that all dimensions are very important in achieving the satisfaction of tourists and thus whenever the workers' performance is the quality of the services provided to the public the best and thus achieve satisfaction (Ljudevit et al,2012).

It was pointed out that there is a direct correlation between the quality of the service provided by the airlines and traveler satisfaction and loyalty; any traveler's loyalty to increase when increasing the quality of service offered to him. He also stressed the need for the airline's keenness to provide all good services to all passengers on its planes (Luai et al,2015). The organizations that sought to keep the tourists and increase loyalty stems from the fact that the cost of acquiring the new customer equivalent to five times the cost of maintaining the current prepayment (Mohammad et al,2014).

And take into account the results of some studies that have shown that it was not necessarily lead to increased loyalty and satisfaction (Natasa ,2005).

In addition to the establishment of relations with tourists and other parties and retained and strengthened and 
sustained to achieve a certain profit, so as to meet the objectives of all the parties concerned through the exchange and joint investigation promises (Sarah et al,2013).

The building topped meaning (Lovelok et al,2008; Satyendra et al,2016; Sayyed et al,2015; Solmaz,2012; Thomas et al,2015; Track,2017; Youngjin,2011).

Increased importance of quality being one of the most important factors in the face of competitors, deductions is distinctive quality is the basis of the differentiation between the sponsors of products when these presentations are similar, it is also important to know the level of standards and performance of organizations, and the essential foundation used by the customer in the discrimination between the real products, and therefore the realization of tourists quality depends on the difference between the quality expected and the perceived quality by tourists (the actual performance of the product), and the quality test here is very difficult; being a true test of the quality of the product from the point of view of the client, it is not enough to make assumptions and provide quality standards, according to the assumptions and expectations of the clients (Yvette and Robert ,2014).

\section{The Methodology}

The descriptive method of searching this which is based on the study of fact or phenomenon and there are, in fact, the general objective of the descriptive method is to reach conclusions and generalizations contributes to understanding this reality and developed.

\section{Research hypotheses}

The hypotheses of the study based on a model of the study and the problem of the study, we can develop the following hypotheses: hypothesis first President: The expectations of the beneficiaries of the quality of the service provided by the Restaurant Royal Marine Sports Federation are low .

The second main premise: the level of awareness of the beneficiaries of the quality of the service provided by the Royal Marine Sports Federation is low.

There are no statistically significant differences between the expectations of the beneficiaries of the Royal Marine Sports Federation, the level of perception to keep the quality of service provided to them .

This hypothesis stems from the following subsidiary hypotheses :

1-There are no statistically significant differences between the expectations of the beneficiaries of Royal Marine Sports Federation, the level of awareness of intangibility dimension .

2- There are no statistically significant differences between the expectations of the beneficiaries of Royal M $\backslash$ rine Sports Federation, the level of awareness of the reliability dimension.

3- There are no statistically significant differences between the expectations of the beneficiaries of the Royal Marine Sports Federation, the level of awareness of the Remoteness of the response .

4- There are no statistically significant differences between the expectations of the beneficiaries of restaurants classified the level of awareness of the security dimension .

5- There are no statistically significant differences between the expectations of the beneficiaries of restaurants classified the level of awareness of the farsightedness of sympathy.

6- There are there are no statistically significant differences in the responses of beneficiaries of Royal Marine Sports Federation on the perceived quality of services provided to beneficiaries due to demographic variables (age, gender, nationality, education, number of visits)

\section{Information Collection Tool}

Which was developed by the Servqual scale has been used to measure the gap between the expectations of the beneficiaries (Parasuraman 1985 Quality of Service before their use and understanding after obtained through the five dimensions of the Chairperson of the quality of the service, a tangibility and reliability and responsiveness and safety, compassion and the elements to be each of dimention where the data collection tool was divided into three sections: The first is the demographic factors, and the second to the expectations of the beneficiary before the receipt of service, and the third for his assessment of the level of service obtained on the Lekart composed of five degrees .

\section{The sincerity and constancy of tool}

To measure the stability of the study tool, it has been using the equation of Cronbach's alpha; where factor alpha93.4\%, which refers to the fact that the study tool flats this ratio is more than $60 \%$ the percentage proposed for this type of research and studies. All of the statements were distributed naturally; where the ratio was less than $5 \%$, which is the level approved for the study. 
Table 1. Cronbach's alpha test results

\begin{tabular}{|l|c|c|}
\hline The variable name & Questions variables & Cronbach's alpha \\
\hline Total & $1-27$ & 0.932 \\
\hline After Tangibles & $1-5$ & 0.725 \\
\hline Reliability & $6-12$ & 0.794 \\
\hline Responding & $13-17$ & 0.686 \\
\hline Empathy & $18-22$ & 0.725 \\
\hline Assurance & $23-27$ & 0.597 \\
\hline
\end{tabular}

Table 2. The study transactions unchanged dimensions of perceived quality variables

\begin{tabular}{|l|c|c|}
\hline The variable name & Questions variables & Cronbach's alpha \\
\hline Total & $1-27$ & 0.876 \\
\hline Tangibles & $1-5$ & 0.509 \\
\hline Reliability & $6-12$ & 0.909 \\
\hline Responding & $13-17$ & 0.791 \\
\hline Empathy & $18-22$ & 0.525 \\
\hline Assurance & $23-27$ & 0.817 \\
\hline
\end{tabular}

Tables 1 and 2 ) unchanged according to Cronbach's alpha internal consistency, the words of the resolution relating to the expected quality-directional, in addition to the dimensions of each of them, all of which indicate that more than $60 \%$ Percentage adopted for this purpose by the researchers in social sciences are greater than $(0.60)$, which is the minimum required $(23,900)$ thousand according to me Joseph Cronbach's alpha, the value of the Alpha coefficient is acceptable, if greater than $(0.60)$ and it can be argued that the standard contained in the previous table has the consistency of procedure interpret.

Table3 .Demographic characteristics of the study sample

\begin{tabular}{|c|c|c|}
\hline The variable & \multirow[t]{2}{*}{ Redundancy } & \multirow[t]{2}{*}{ Percentage } \\
\hline Sex & & \\
\hline Male & 80 & $33.3 \%$ \\
\hline Female & 160 & $66.7 \%$ \\
\hline \multicolumn{3}{|l|}{ Age } \\
\hline Less than 25 & 172 & $72 \%$ \\
\hline $26-35$ & 48 & $20 \%$ \\
\hline $36-45$ & 16 & $7 \%$ \\
\hline $46-55$ & 4 & $2 \%$ \\
\hline More than 56 & 0 & $0 \%$ \\
\hline \multicolumn{3}{|l|}{ Nationality } \\
\hline Jordanian & 204 & $85 \%$ \\
\hline Arabic & 32 & $13 \%$ \\
\hline The European & 4 & $2 \%$ \\
\hline Asian & 0 & $0 \%$ \\
\hline--- & 0 & $0 \%$ \\
\hline Others & 0 & $0 \%$ \\
\hline \multicolumn{3}{|l|}{ Educational level } \\
\hline secondary & 40 & $17 \%$ \\
\hline Diploma & 28 & $12 \%$ \\
\hline Bachelor & 160 & $67 \%$ \\
\hline Postgraduate Studies & 12 & $5 \%$ \\
\hline \multicolumn{3}{|l|}{ The number of visits } \\
\hline One Visit & 32 & $13 \%$ \\
\hline $2-4$ & 84 & $35 \%$ \\
\hline $5-7$ & 32 & $13 \%$ \\
\hline 8.10 & 28 & $12 \%$ \\
\hline More than 11 & 64 & $27 \%$ \\
\hline
\end{tabular}

The table shows (3) that the proportion of female visitors than visitors from male, perhaps because females are more hesitant to Royal Marine Sports Federation of male, this may be due to the work of women and preoccupation for the preparation of food in the house. As is clear from the same table that more than half of the study sample are aged under the age of 25 years, and that the proportion of persons aged over 45 years does not exceed $\% 7$ This is relatively consistent with the age distribution of the population; where the majority of the 
kingdom's population are young people and young people. As for the educational level, the table shows that the category of the first university-level education bachelor's degree constitute the largest segment of visitors to the Royal Marine Sports Federation , while high certificates do not represent more than $5 \%$ of the study sample, can be interpreted as an increase in the numbers of the category bachelor's degree for several reasons, including the fact that the size of this category in the society, and that this category prefer to dine outside houses, as well as prefer fast food more than other age groups. Ratio of nationality obtained Jordanian nationality to more than half the $\% 85$, which shows that the number of visitors, most of the same nationality of the State in which there is a Royal Marine Sports Federation, the ratio of the number of visits received 2.4 visits the highest rate of $35 \%$ in the second more than 11 visit by $27 \%$.

\section{Discussion}

It has been the use of descriptive statistical methods and the standard deviation, duplicates, and ratios to describe the characteristics of the sample respondents answers the dimensions of quality, were also used to analyze the results of the f-test and t-test correlation coefficient and decadence and contrast study and test the hypotheses. The researchers was adopted on the basis of comparing the expectations of the beneficiary to keep the elements of quality compared with the actual level of awareness by the beneficiary if the difference between the level of actual awareness of the quality and level of positive expectations, this means that the beneficiary, was satisfied with the level of service provided by being more than its expectations, if negative, this means that the realized what happened was less than expectations. This refers to the dissatisfaction with the level of service provided, the following simple equation that means the quality aware, and means the expected quality, means the level of satisfaction.

It is clear from the tables (5.4, there are significant differences between expected values - being aware of each one of the dimensions of quality of service, and that this difference was on the whole is negative for all multidimensional; that is, the quality expected, was higher than the perceived quality, though there are positive differences to certain elements of the service as will be explained in the analysis of the tables to articulate:

Table 4. The difference between the average expectations of the beneficiaries of the dimensions of quality

\begin{tabular}{|c|c|c|c|c|c|c|}
\hline $\begin{array}{l}\text { Quality } \\
\text { Expected } \\
\text { accomplishments }\end{array}$ & $\begin{array}{l}\text { The } \\
\text { Arithmetic }\end{array}$ & $\begin{array}{l}\text { Standard } \\
\text { Deviation }\end{array}$ & $\begin{array}{l}\text { Quality } \\
\text { Aware of the }\end{array}$ & $\begin{array}{l}\text { The } \\
\text { Arithmetic }\end{array}$ & $\begin{array}{l}\text { Standard } \\
\text { Deviation }\end{array}$ & $\begin{array}{l}\text { The } \\
\text { differences }\end{array}$ \\
\hline The quality expected & 4.00 & 0.597 & $\begin{array}{l}\text { The perceived } \\
\text { quality of }\end{array}$ & 3.73 & 0.47 & -0.27 \\
\hline Tangibles & 4.21 & 0.54 & $\begin{array}{l}\text { Concrete } \\
\text { actions }\end{array}$ & 3.98 & 0.54 & -0.23 \\
\hline The reliability & 3.83 & 0.66 & The reliability & 3.63 & 0.58 & -0.2 \\
\hline To respond to the & 4.03 & 0.69 & $\begin{array}{l}\text { To respond to } \\
\text { the }\end{array}$ & 3.74 & 0.70 & -0.29 \\
\hline Empathy & 3.82 & 0.68 & $\begin{array}{ll}\text { Care } & \text { and } \\
\text { attention. } & \end{array}$ & 3.48 & 0.622 & -0.34 \\
\hline Assurance & 4.13 & 0.73 & The Warranty & 3.80 & 0.750 & -0.33 \\
\hline
\end{tabular}

Table (5) the difference between the average و إدر اكاتهم the expectations of the beneficiaries of the elements of the dimensions of quality.

\begin{tabular}{|l|l|l|l|l|l|l|l|}
\hline $\begin{array}{l}\text { Quality } \\
\text { Expected } \\
\text { accomplishments }\end{array}$ & The & $\begin{array}{l}\text { Standard } \\
\text { Deviation }\end{array}$ & The variables & Quality & $\begin{array}{l}\text { The } \\
\text { Center }\end{array}$ & $\begin{array}{l}\text { Standard } \\
\text { Deviation }\end{array}$ & $\begin{array}{l}\text { The } \\
\text { differences }\end{array}$ \\
\hline TEQ1 & 4.35 & 0.77 & $\begin{array}{l}\text { An appropriate } \\
\text { staff uniforms and } \\
\text { clean. }\end{array}$ & TPQ1 & 4.26 & 0.63 & -0.09 \\
\hline TEQ2 & 4.11 & 0.73 & $\begin{array}{l}\text { The staff provide } \\
\text { services with a } \\
\text { smile. TPQ2 }\end{array}$ & 3.73 & 0.95 & -0.38 \\
\hline TEQ3 & 4.16 & 0.86 & $\begin{array}{l}\text { The Royal Marine } \\
\text { Sports Federation } \\
\text { has TPQ3 } \\
\text { equipment. }\end{array}$ & 3.98 & 0.83 & Bovespa \\
\hline
\end{tabular}




\begin{tabular}{|c|c|c|c|c|c|c|c|}
\hline $\begin{array}{l}\text { Quality } \\
\text { Expected } \\
\text { accomplishments }\end{array}$ & The & $\begin{array}{l}\text { Standard } \\
\text { Deviation }\end{array}$ & The variables & Quality & $\begin{array}{l}\text { The } \\
\text { Center }\end{array}$ & $\begin{array}{l}\text { Standard } \\
\text { Deviation }\end{array}$ & $\begin{array}{l}\text { The } \\
\text { differences }\end{array}$ \\
\hline TEQ4 & 4.05 & 0.76 & $\begin{array}{l}\text { The Royal Marine } \\
\text { Sports Federation } \\
\text { has attractive } \\
\text { modern facilities. }\end{array}$ & TPQ4 & 3.7 & 1.09 & -0.35 \\
\hline TEQ5 & 4.36 & 0.80 & $\begin{array}{l}\text { The opening times } \\
\text { of the Royal Marine } \\
\text { Sports Federation }\end{array}$ & TPQ5 & 4.2 & 0.85 & -0.16 \\
\hline REQ6 & 3.81 & 1.08 & $\begin{array}{l}\text { The Group could } \\
\text { work to provide } \\
\text { services ror } \\
\text { example promotion }\end{array}$ & RPQ6 & 3.6 & 1.10 & -0.21 \\
\hline REQ7 & 3.73 & 0.86 & $\begin{array}{l}\text { The provision of } \\
\text { accurate } \\
\text { information. }\end{array}$ & RPQ7 & 3.63 & 0.88 & -0.10 \\
\hline REQ8 & 3.51 & 1.06 & $\begin{array}{l}\text { Give Royal Marine } \\
\text { Sports Federation } \\
\text { officials cust }\end{array}$ & RPQ8 & 3.35 & 1.07 & -0.16 \\
\hline REQ9 & 3.78 & 1.04 & $\begin{array}{l}\text { Deal Royal Marine } \\
\text { Sports Union staff } \\
\text { with clients very } \\
\text { carefully. }\end{array}$ & RPQ9 & 3.51 & 1.14 & -0.27 \\
\hline REQ10 & 3.93 & 0.95 & $\begin{array}{l}\text { The Royal Marine } \\
\text { Sports Union staff } \\
\text { the client's interest } \\
\text { above all. }\end{array}$ & RPQ10 & 3.6 & 0.90 & -0.33 \\
\hline REQ11 & 4.06 & 0.82 & $\begin{array}{l}\text { The staffs } \\
\text { understand the } \\
\text { needs of customers. }\end{array}$ & RPQ11 & 3.93 & 0.86 & -0.13 \\
\hline REQ 12 & 3.98 & 1.04 & $\begin{array}{l}\text { The Assistant staff } \\
\text { to give you. }\end{array}$ & RPQ12 & 3.8 & 0.89 & Bovespa \\
\hline RSEQ13 & 4.08 & 0.84 & $\begin{array}{l}\text { The staff offers } \\
\text { quick }\end{array}$ & RSPQ13 & 3.8 & 0.93 & -0.28 \\
\hline RSEQ14 & 4.06 & 0.91 & $\begin{array}{l}\text { The staffs are ready } \\
\text { to help you for } \\
\text { example striking } \\
\text { toe Royal Marine } \\
\text { Sports Federation. }\end{array}$ & RSPQ14 & 3.76 & 0.94 & -0.3 \\
\hline RSEQ15 & 3.95 & 0.96 & $\begin{array}{l}\text { The staffs provide } \\
\text { the } \\
\text { required. }\end{array}$ & RSPQ15 & 3.65 & 0.97 & -0.3 \\
\hline RSEQ16 & 3.96 & 0.84 & $\begin{array}{l}\text { You can count on } \\
\text { the staff in } \\
\text { addressing the } \\
\text { problems of the } \\
\text { customer. }\end{array}$ & RSPQ16 & 3.61 & 1.00 & -0.35 \\
\hline RSEQ17 & 4.06 & 0.88 & $\begin{array}{l}\text { The staff services } \\
\text { are correctly } \\
\text { completed and on } \\
\text { time. }\end{array}$ & RSPQ17 & 3.86 & 0.92 & -0.2 \\
\hline EMEQ18 & 3.96 & 0.93 & $\begin{array}{l}\text { Staffs are able to } \\
\text { communicate with } \\
\text { you in English. }\end{array}$ & EMPQ18 & 3.41 & 0.99 & -0.55 \\
\hline EMEQ19 & 3.98 & 0.92 & $\begin{array}{l}\text { Staffs are able to } \\
\text { communicate } \\
\text { effectively. }\end{array}$ & EMPQ19 & 3.62 & 0.99 & -0.36 \\
\hline
\end{tabular}




\begin{tabular}{|c|c|c|c|c|c|c|c|}
\hline $\begin{array}{l}\text { Quality } \\
\text { Expected } \\
\text { accomplishments }\end{array}$ & The & $\begin{array}{l}\text { Standard } \\
\text { Deviation }\end{array}$ & The variables & Quality & $\begin{array}{l}\text { The } \\
\text { Center }\end{array}$ & $\begin{array}{l}\text { Standard } \\
\text { Deviation }\end{array}$ & $\begin{array}{l}\text { The } \\
\text { differences }\end{array}$ \\
\hline EMEQ20 & 3.05 & 1.30 & $\begin{array}{l}\text { The staffs know } \\
\text { your information. }\end{array}$ & EMPQ20 & 2.75 & 1.22 & -0.3 \\
\hline EMEQ21 & 4.1 & 0.85 & $\begin{array}{lr}\text { Staffs } & \text { were } \\
\text { courteous } & \text { and } \\
\text { friendly. } & \\
\end{array}$ & EMPQ21 & 3.91 & 0.94 & -0.19 \\
\hline EMEQ22 & 3.98 & 0.89 & $\begin{array}{l}\text { The staffs have full } \\
\text { knowledge to } \\
\text { answer the } \\
\text { questions of the } \\
\text { customer. }\end{array}$ & EMPQ22 & 3.65 & 0.86 & -0.33 \\
\hline ASEQ23 & 4.08 & 0.90 & $\begin{array}{l}\text { Job lolayates have } \\
\text { knowledge of the } \\
\text { services provided to } \\
\text { all components } \\
\text { although example } \\
\text { describes the meals. }\end{array}$ & ASPQ23 & 3.78 & 0.92 & -0.3 \\
\hline ASEQ24 & 4.11 & 0.88 & $\begin{array}{l}\text { The staffs speak } \\
\text { with you in an } \\
\text { appropriate } \\
\text { manner. }\end{array}$ & ASPQ24 & 3.8 & 0.93 & -0.31 \\
\hline ASEQ25 & 4.03 & 0.91 & $\begin{array}{l}\text { The staffs are } \\
\text { trustworthy. }\end{array}$ & ASPQ25 & 3.55 & 1.01 & -0.48 \\
\hline ASEQ 26 & 4.16 & 0.80 & $\begin{array}{l}\text { The staffs make } \\
\text { you feel safe when } \\
\text { you stay. }\end{array}$ & ASPQ 26 & 3.85 & 0.86 & -0.31 \\
\hline ASEQ27 & 4.26 & 1.08 & $\begin{array}{l}\text { The staffs are } \\
\text { always ready to } \\
\text { respond to the } \\
\text { requests of clients. }\end{array}$ & ASPQ27 & 4 & 1.08 & $\begin{array}{l}\text { Market is } \\
\text { also } \\
\text { experiencing }\end{array}$ \\
\hline
\end{tabular}

It is clear from the table (5.4) that the average expected value of the elements of the dimensions of quality were mostly negative, in the sense that the perceived value was less than the expected value of 0.27 , this difference is up to 0.43 in after the attention and care component and ياللغة Speak English with tourists by the staff of the Royal Marine Sports Federation with a difference of 0.55 , followed with a difference of 0.33 , security on, on the 285,200 shown trustworthy 0.48 .

\section{Test Hypotheses}

The hypothesis first president HO1 the level of expectations of the beneficiaries of the quality of the service provided by the Royal Marine Sports Federation is low.

Using test One Sample T Test sample per T to deny the hypothesis first president of zero or proven; where the following table shows the results of this test:

Table 6: the expected level of quality of the sample per

\begin{tabular}{|l|l|l|l|l|}
\hline The variable & $\begin{array}{l}\text { The Center } \\
\text { Arithmetic }\end{array}$ & $\begin{array}{l}\text { The Deviation } \\
\text { The standard }\end{array}$ & $\begin{array}{l}\text { The value of the } \\
\text { T }\end{array}$ & $\begin{array}{l}\text { The Level } \\
\text { Morale }\end{array}$ \\
\hline The quality expected & 4 & 0.597 & 23.69 & 0.00 \\
\hline
\end{tabular}

The table shows (6) Calculated أن (23.69) than the tabular value, and therefore reject the zero hypothesis and accept the alternative hypothesis which states that the level of the expectations of the beneficiaries of the quality of the service provided by the Royal Marine Sports Union High. And confirms the correctness of this decision is that the level of morale shown in the same table was zero, which is less than the level for the study of 0.05 .

The second main hypothesis HO2 thelevel of awareness of the beneficiaries of the quality of the service provided to the P-4 Royal Marine Sports Federation is low.

Using test One Sample T Test sample per T to deny the hypothesis first president of zero or proven; where the following table shows the results of this test: 
Table (7) perceived quality level per sample

\begin{tabular}{|l|l|l|l|l|}
\hline The variable & Arithmetic & Standard Deviation & The value of the T & Level Morale \\
\hline The perceived quality of & 3.73 & 0.47 & 23.29 & 0.00 \\
\hline
\end{tabular}

The table shows ( 7) that the value of (23.29) is the largest of the Tabular trend value, and therefore reject the zero hypothesis

And accept the alternative hypothesis that the level of awareness of the beneficiaries of the quality of the service provided in the Royal Marine Sports Union High.

And confirms the correctness of this decision is that the level of morale shown in the same table was zero, which is less than the level for the study of $\$ 0.05$

Third Main hypothesis HO3 there is no statistically significant differences between the expectations of the beneficiaries in the Royal Marine Sports Federation, the level of perception to keep the quality of service provided to them.

The use of the analysis of the samples have been ختبارT bilateral T-test Paired Sampleto deny the hypothesis of zero or the third main proved; T Test, as the following table shows the results of this test:

Table 8. Analysis of the differences between the quality expected perceived quality

\begin{tabular}{|l|l|l|l|}
\hline The two variables & T & The level of morale & Resolution \\
\hline $\begin{array}{l}\text { The quality expected } \\
\text { The perceived quality of }\end{array}$ & 4.283 & 0.00 & The refusal \\
\hline
\end{tabular}

Table ( 8) indicates that the results of the analysis of the differences between the quality expected by beneficiaries in the Royal Marine Sports Federation , the perceived quality have shows that there are significant differences between the samples T quality expected perceived quality; where the value of bilateral (4.283), which requires zero refused to accept the alternative hypothesis the hypothesis that the existence of such a relationship, and confirms that the level of morale was zero, less than $5 \%$ the ratio in this study. To verify the hypotheses of these thesis bilateral $\mathrm{T}$ samples of the Chairperson, the analysis of the test has been used to deny the assumptions of zero subcommittee or Paired Sample T Testproved; where the following table shows the results of this test:

Table 9. Analysis of the differences between the dimensions of quality expected perceived quality

\begin{tabular}{|l|l|l|c|}
\hline Resolution & Level Morale & T & The variables \\
\hline The refusal & .006 & 2.94 & The perceived expected \& Tangibles \\
\hline The refusal & 0.019 & 2.14 & The perceived expected \& Reliability \\
\hline The refusal & 0.000 & 3.32 & Expected response \& aware \\
\hline The refusal & 0.000 & 4.12 & The perceived expected sympathy \& \\
\hline The refusal & 0.000 & 3.80 & The perceived expected \& Safety \\
\hline
\end{tabular}

\section{The first hypothesis}

There are no statistically significant differences between the expectations of the beneficiaries in the Royal Marine Sports Federation, the level of awareness of Tangibles dimension.

Bilateral samples (table9) to $\mathrm{T}$ results indicate the calculated test was 2.94 accordingly reject the zero hypothesis and accept the alternative hypothesis, which provides for the presence of statistically significant differences between the expectations of the beneficiaries in the Royal Marine Sports Federation , the level of awareness of the Remoteness of Tangibles, and confirms that the level of morale was 0.006, less than $\% 5$ percentage adopted in this study.

\section{The second sub-hypothesis}

There are no statistically significant differences between the expectations of the beneficiaries in the Royal Marine Sports Federation, the level of awareness of the reliability dimension.

Bilateral samples (table9) to $\mathrm{T}$ results indicate the calculated test was 2.14 accordingly reject the zero hypothesis and accept the alternative hypothesis that states the existence of statistically significant differences between the expectations of the beneficiaries in the Royal Marine Sports Federation, the level of awareness of the reliability dimension, and confirms that the level of morale was 0.011 , less than $5 \%$ the ratio in this study.

\section{The third sub-hypothesis}

There are no statistically significant differences between the expectations of the beneficiaries in the Royal Marine Sports Federation, the level of awareness of the Remoteness of the response.

Bilateral samples (table9) to $\mathrm{T}$ results indicate the calculated test was 3.32 accordingly reject the zero hypothesis and accept the alternative hypothesis that states the existence of statistically significant differences between the expectations of the beneficiaries in the Royal Marine Sports Federation, the level of awareness of the Remoteness of the response, and confirms that the level of morale of Sudan Airways was zero, less than $\% 5$ percentage adopted in this study. 


\section{The hypothesis fourth subparagraph}

There are no statistically significant differences between the expectations of the beneficiaries in the Royal Marine Sports Federation, the level of awareness of the security dimension.

Bilateral samples (table9) to $\mathrm{T}$ results indicate the calculated test was 3.80 accordingly reject the zero hypothesis and accept the alternative hypothesis, which provides for the presence of statistically significant differences between the expectations of the beneficiaries in the Royal Marine Sports Federation, the level of awareness of the Remoteness of the emphasis, and this confirms that the level of morale was zero, less than 5\% in this study.

\section{The hypothesis fifth subparagraph}

There are no statistically significant differences between the expectations of the beneficiaries in the Royal Marine Sports Federation, the level of awareness of the farsightedness of sympathy.

Bilateral samples (table9) to $\mathrm{T}$ results indicate the calculated test was 4.12 accordingly reject the zero hypothesis and accept the alternative hypothesis, which provides for the presence of statistically significant differences between the expectations of the beneficiaries in the Royal Marine Sports Federation, the level of awareness of the Remoteness of the sympathy, and confirms that the level of morale was zero, which is less than $5 \%$ the ratio in this study.

There is no statistically significant differences in the responses of the beneficiaries of the Royal Marine Sports Federation in the perceived quality of the services provided due to demographic variables and the beneficiaries (sex, age, nationality, education level, number of visits).

In order to test the validity of this assumption, the variance analysis test plan.One Way Anova

The results of the test the hypothesis, as shown in the following table:

Table 10 . Analysis of differences in the perceived quality of the beneficiaries of the answers depending on demographic variables

\begin{tabular}{|l|l|l|}
\hline Demographic variables & F & The level of significance \\
\hline Sex & 3.455 & 0.045 \\
\hline Age & 0.725 & 0.90 \\
\hline Nationality & 0.658 & 0.324 \\
\hline Educational level & 0.428 & 0.676 \\
\hline The number of visits & 2.368 & 0.116 \\
\hline
\end{tabular}

The results of the table ( 10 ) to the existence of statistically significant differences in the responses of the beneficiaries of the perceived quality of $\mathrm{T}$ depending on the sex variable only, to the moral level of $\$ 0.045$, which is less than 5\% percentage approved for this study. The rest of the other variables (age, sex, education, homosexual relationships, the number of visits) results indicate the absence of statistically significant differences in the responses of beneficiaries in the Royal Marine Sports Federation for the perceived quality of the services provided due to these variables, this decision confirms the moral level of the variables that have increased $5 \%$ percentage approved for this study.

\section{The discussion of the results}

Based on the analysis of the results that the difference between the average total medium product realization is anticipated negative teams agenda)4) This is an indicator

On the level of satisfaction with the services in the Royal Marine Sports Federation was relatively acceptable, but the expected value that was higher than the perceived value, this indicates a deficiency in the level of quality of servies present -directional by beneficiaries of the expected level after receiving the service, this despite the fact that both the brokers. The perceived expected) were higher than the average value of the study, the degree of utility, this is proof that the consent to a center exists, but the aspiration of the beneficiaries (expected) is higher than what they got, pushing the royal marine sports union administration the need to upgrade its services to increase; the level of quality of these services and access to a higher level of satisfaction to the beneficiaries in order to cope with their expectations and bridge the tour occurring between the average total value of the total value of the perceived average expected.

In relation to the five dimensions of service quality, safety, reliability, and responsiveness to Tangibles and compassion,

The findings indicated that they were all negative, table)4); the negative difference between the average aware the average expectations of each of these dimensions indicates that the level of perceived quality after receiving the service is less than the level of quality expected before receiving service and all these dimensions, which means that the management of the Royal Marine Sports Federation work to improve the level of services provided to beneficiaries in every dimension of the quality of the service in order to equal or exceed the expectations of the beneficiaries, note that the evaluation of the beneficiaries all dimensions was higher than the average value of the window of the study, this is an indicator of the presence of a medium level of satisfaction with the dimensions of 
the quality of the service provided by the Department of Royal Marine Sports Federation.

We find that after the care and attention (sympathy) had been the top measured the average answers respondents (3.61) and it was after attention and care at least aware ( \$3.48) as was the largest differences between the expected value-directional is $(0.34)$ on the foresight and attention and less, the differences was $(0.2)$ concerning, showed the study sample Anna there is an acceptable level of satisfaction) is expected), the perceived after Tangibles; where the average answers more than 4 degrees, which is the value ok according to likert system, but the difference was in favor of the expected value; where the difference between the perceived value (3.98) the expected value (4.21) (0.23) This refers to the existence of a gap between the perceived values (projected), was The biggest differences of elements after Tangibles is on staff provides services with a smile, and least on the uniform of suitable staff, clean and, accordingly, we find that the management of the royal marine sports in the need for increased attention to Tangibles dimension and its various elements, especially with regard to the staff with a smile, and be at a level appropriate to the expectations of the beneficiaries, stressing that, according to the answers to the sample study, the perceived value is higher than the average, and this in itself is good, but needs to be improved; the expectations of the beneficiaries of the services of the Royal Marine Sports Federation of more than what they get.

The comparison of the average answers to the study sample, the expected value-directional reliability dimension (table 4) We find that the difference $(-0.2)$ was negative, which indicates that the perceived value is less than the value of the Royal Marine Sports Union needs the attention of the Department of Royal Marine Sports Federation. where the average answers more than 3 degrees, to return to the elements of reliability, of broken promises and attention to the problems of the beneficiaries and precision in the performance of the work of the first time and service in a timely and accurate records, as in table (5), we find the largest differences is on the performance of the work ( Puts Royal Marine Sports Union staff the client's interest above all) by (0.33), and the least who definition (the provision of staff Accurate information) (0.10), this may indicate that the weakness of any element of the dimensions of the quality of service that could affect the final assessment of the quality of the service, the Library Administration work to know the reason for this discrepancy between elements after the interdependence and in particular, to address the problems of the beneficiaries and the accuracy of the performance.

A chart of the results of the study that the difference between the perceived value of the expected value of the farsightedness of response was(-.029 (negative, which means that the expected value is greater than the perceived value, where the average answers was 4degrees, to return to the elements of the response to compare the elements after responding to find that this dimension had included several elements: the declaration at the time of the performance of the service, the provision of immediate services, help beneficiaries and devote themselves to the service, as in table (5) We find the largest differences is on full-time service ( can count on the staff in addressing the problems of the customer) by $(0.35)$, and the least on the declaration at the time of duty ( perform staff services are correctly, on time, by $(0.2)$, this requires that the library management Know the reasons that led to this gap and addressed to upgrade the quality of services after responding to the expectations of the beneficiaries.

The results of the study showed that the difference between the perceived value (the expected value) for the security dimension $(-0.33)$ is negative, this indicates a decline in the perceived value of the security dimension of the quality expected him, come from; where the amount of the difference in the second after care and attention (empathy), this refers to the size of the gap between the expected value by beneficiaries perceived value, which leads us to emphasize the need for attention to this dimension of the Department of Royal Marine Sports Federation. In view of the elements of this dimension we find it consists of self-confidence, and a feeling of security, and fitness literature in dealing, staff training, including qualifying them to serve the beneficiaries, the differences are all negative, as summarized inthe(5) means that the perceived value of all these elements were less than the expected value, the largest variances.0.48(on the element of confidence and least component of literature in dealing $(0.26)$ This emphasizes the need for attention to the element of the security (Empathy) especially confidence with tourists to increase the level of satisfaction with the perceived value of the security dimension (Empathy).

The results of the study showed, referred to in the table No. (4) the existence of a gap between the perceived value of the expected value of the farsightedness of sympathy $(-0.34)$; where the perceived value was less than the expected value, which means that the level of quality of service received by the evaluation of tourists is less than the level at which they expect, it has been shown in table (6) that the constituent elements of this dimension, we find that it consists of personal attention and understanding of needs beneficiaries and the appropriateness of the hours of work and there is parking and the existence of educational programs, it was the largest differences on the element of trust by (0.55), and the least on the nice staff by (0.19) Accordingly, the management of the Royal Marine Sports Federation need to know the causes of the gap and to reach the level of the expectations of the beneficiaries.

As for the demographic factors, the results of the study indicated that, with the exception of sex, there were no differences in 5,955

Respondents depending on demographic variables and this finding was confirmed through the test of these 
combined variables as in table (10); where there were no statistically significant differences, this indicates that the respondents to the evaluation of the quality of services in the Royal Marine Sports Federation was homogeneous regardless of the demographic characteristics.

\section{Recommendations:}

We can through the results of the Marketing content that we recommend the following:

The need for attention to quality from the perspective of the recipient, not only from the perspective of the service provider; the judgment on the service of the Mix and match technically the conditions and specifications defined by the organization and its success in this may not give the same result from the point of view of the beneficiaries of the service, and this was clear in all results; where there was a gap between expected perceived all dimensions and elements of quality.

The need for comprehensive attention to quality as an input from the entrances of quality management as it deals with the quality of service, which gives the chance to manage the Organization to identify strengths and weaknesses and guide their efforts, and lead to the upgrading of the service. That the department in the Royal Marine Sports Union to work to bridge the gap between the expected value of the perceived quality and value and all dimensions, so that we can get the required level of acceptance and satisfaction. Necessary in the Royal Marine Sports Federation attention to research and studies in the field of quality of services and follow-up of all the developments in this area to benefit from the observations and suggestions of the beneficiaries of the services they are best able to assess the level of quality of these services.

The need to develop an information base on the beneficiaries of the services of the Royal Marine Sports Federation, through cards include demographic information and personal information on the beneficiary and the quality of benefit and periods of benefit and continuity of the frequency on the Royal Marine Sports Federation; because this helps the management of the Royal Marine Sports Union to know their customers better, and redesign their services on the basis of this information.

The spatial expansion, any geographical proliferation is an expensive being needs to land and buildings, staff and facilities

Many, especially the city of Aqaba is the fast-growing cities demographically and geographically, and this makes it difficult for the management of the Royal Marine Sports Federation keep pace with this rapid growth, with the note that the branches of the Royal Marine Sports Federation is widespread in the capital Amman and here we propose the expansion of services electronic appliances so that the subscriber can benefit from the services of the Royal Marine Sports Federation through the Internet.

The human interest efficient cadres of the restaurant any service providers, and this is an important element of the marketing mix and service, which means the necessity to interest the appearance of the workers, training and rehabilitation to deal with all categories of tourists and help these tourists to benefit from the services of the Royal Marine Sports Federation.

\section{Referance}

Abu Rumman, M., Jawabreh, O., Alhyasat, K., \& Husam, H. (2013). The impact of work environment on the average of job turnover in five-star hotels in Al-aqaba city. Business Management and Strategy, 4(2). https://doi.org/10.5296/bms.v4i2.402.

Alananzeh, O., Masa'deh, R., Jawabreh, O., Al-Mahmoud, A., \& Hamada, R. (2018). The impact of customer relationship management on tourist satisfaction: The case of Radisson Blue Resort in Aqaba city. Journal of Environmental Management and Tourism, 2(26), 227-240 .

Al-Hussein, M., Jawabreh, O., Alananzeh, O., \& Ali, M. (2015). The impact of understanding the behavior of workers on the success of management, (a case study of five star hotels in Aqaba). Journal of Management Research, 7(3), 51-70. https://doi.org/10.5296/jmr.v7i3.7115.

Alsarayreh ,M., ALdmour ,A., Jawabreh,O( 2015a),Recreational tourism programs (extracurricular) provided to delegations participating in sports championships organized in Jordan (from the point of view of sports tourist, The WEI International Academic Conference, Barcelona,Spain.

Alsarayreh ,M., ALdmour ,A., Jawabreh,O( 2015b), The role of sports events in the revitalization of touristic movement from the perspective of the tourist (Golden triangle case study). Research Journal of International Studies - Issue 21,

ALsarayreh,M.Jawabreh,O. ALkharabsheh,K. Aldahamsheh,M.(2011). Tourism Promotion through the Internet (Websites) (Jordan as a Case Study), Asian Social Science, Vol. 7, No. 6; doi:10.5539/ass.v7n6p125.

Al-Shawagfih, K., Alananzeh, O., \& Jawabreh, O. (2015). The foundations of selecting cultural tourism product in Jordan. European Scientific Journal, 11(29).

Adrian Devine, Emily Boyle, Stephen Boyd, (2011) "Towards a theory of collaborative advantage for the sports tourism policy arena", International Journal of Public Sector Management, Vol. 24 Issue: 1, pp.23-41, https://doi.org/10.1108/09513551111099208. 
Amyan, M., \& Jawabreh, O. (2011). Mutual impact between tourism and the host community (a case study of Wadi Rum. European Journal of Social Sciences, 19(1).

Anne-Mette Hjalager, (2001) "Quality in tourism through the empowerment of tourists", Managing Service Quality: An International Journal, Vol. 11 Issue: 4, pp.287-296, https://doi.org/10.1108/09604520110397995.

Bazazo, Ibrahim; Alshatnawi, Ehab Abdul Raheem; Jawabreh, Omar; Alshawagfih, Kafeh Fare Alnahar (2017); The Effect of Adopting the International Standard (ISO 10015) in Training Programs on the Performance Quality of the Workers at the Jordanian Ministry of Tourism and Antiquities; Journal of Social Sciences (COES\&RJ-JSS), Vol.6, No.3, pp:694-708; https://doi.org/10.25255/jss.2017.6.3.694.708.

Chris A. Vassiliadis , , Anestis Fotiadis , (2016), Managing Sport Tourism Experiences: Blueprinting Service Encounters, in Marios Sotiriadis , Dogan Gursoy (ed.) The Handbook of Managing and Marketing Tourism Experiences, pp.195 - 215 .

Cong Chi Le, Dam Xuan Dong, (2017) "Factors affecting European tourists' satisfaction in Nha Trang city: perceptions of destination quality", International Journal of Tourism Cities, Vol. 3 Issue: 4, pp.350-362, https://doi.org/10.1108/ IJTC-04-2017-0022.

Crystal C. Lewis , , Cristina H. Jönsson , (2016), Promotion Tools Used in the Marketing of Sport Tourism Experiences in a Mature Tourism Destination, in Marios Sotiriadis , Dogan Gursoy (ed.) The Handbook of Managing and Marketing Tourism Experiences, pp.397 - 407.

Dongfeng Liu, (2016) "Social impact of major sports events perceived by host community", International Journal of Sports Marketing and Sponsorship, Vol. 17 Issue: 1, pp.78-91, https:// doi.org/10.1108/IJSMS-02-2016005 .

Donald Sinclair, (2005) "Sports education - a priority for Caribbean sports tourism", International Journal of Contemporary Hospitality Management, Vol. 17 Issue: 6, pp.536-548, https:// doi.org/10.1108/09596110510612176.

Girish Ramchandani, Richard J. Coleman, Jerry Bingham, (2017) "Sport participation behaviours of spectators attending major sports events and event induced attitudinal changes towards sport", International Journal of Event and Festival Management, Vol. 8 Issue: 2, pp.121-135, https:// doi.org/10.1108/IJEFM-02-2016-0014.

Grzegorz Kwiatkowski, Thomas Könecke, (2017) "Tourism and recurring sport events: Event tourists' and regular tourists' profiles and expenditures at the Windsurf World Cup on Sylt", Sport, Business and Management: An International Journal, Vol. 7 Issue: 5, pp.464-482, https://doi.org/10.1108/ SBM-11-2016-0070.

Ho Keun Choo, Yunjeong (Clara) Choo, Hyun Min Kang, (2016) "Do sport tourists' perceived risks affect their involvement and intention to (re)visit? An empirical study for risk-reduction strategies", International Journal of Sports Marketing and Sponsorship, Vol. 17 Issue: 1, pp.19-36, https:// doi.org/10.1108/IJSMS-02-2016002 .

Jawabreh,O.(2014a).The Impact of Customer Relationship Marketing by Aqaba Economic Zone "A Case Study of Five Stars Hotels", International Journal of Academic Research in Accounting, Finance and Management Sciences, Vol. 4, No.1, http://dx.doi.org/10.6007/IJARAFMS/v4-i1/583.

Jawabreh,O. Al Sarayreh, M .(2017). Analysis of job satisfaction in the hotel industry: A study of hotels five- Stars in Aqaba special economic zone authority (AZEZA), International Journal of Applied Business and Economic Research,15 19 (Part-II), 407 - pp.389.

Jawabreh.O,Alananzeh.O,Shatnawi.H.(2015). Managing Tourism Effects for Attitudes of Jordanians Towards Tourism: The Case of Petra,European Journal of Social Sciences, Vol. 48 No 1.

Jawabreh, O., Al Jaffal, T., Abdelrazaq, H., \& Mahmoud, R. (2018). The Impact of Menus on the Customer Satisfaction in Restaurants Classified in Aqaba Special Economic Zone Authority (ASEZA), Journal of Tourism, Hospitality and Sports, 33.

Jawabreh, O. (2017b). Distinction of Jordan as a destination for religious tourism. Journal of Environmental Management and Tourism, 6(22), 1171-1182. https://doi.org/10.14505/jemt.v8.6(22).03.

Jawabreh, O. (2017c). An exploratory study of the motives of Jordanian out bound tourism and its impact on the development of tourism in Jordan. International Journal of Applied Business and Economic Research, 15(19 Part-II), 443-467.

Jiaying Lyu, Liang Hu, Kam Hung, Zhenxing Mao, (2017) "Assessing servicescape of cruise tourism: the perception of Chinese tourists", International Journal of Contemporary Hospitality Management, Vol. 29 Issue: 10, pp.2556-2572, https://doi.org/10.1108/IJCHM-04-2016-0216.

J. Lucy Lee, Yukyoum Kim, June Won, (2018) "Sports brand positioning: Positioning congruence and consumer perceptions toward brands", International Journal of Sports Marketing and Sponsorship, Vol. 19 Issue: 4, pp.450-471, https://doi.org/10.1108/IJSMS-03-2017-0018

Joan C. Henderson, Ken Foo, Hermes Lim, Serene Yip, (2010) "Sports events and tourism: the Singapore Formula One Grand Prix", International Journal of Event and Festival Management, Vol. 1 Issue: 1, pp.60-73, https://doi.org/10.1108/17852951011029306.

Klaus Weiermair, (2000) "Tourists' perceptions towards and satisfaction with service quality in the cross-cultural 
service encounter: implications for hospitality and tourism management", Managing Service Quality: An International Journal, Vol. 10 Issue: 6, pp.397-409, https://doi.org/10.1108/09604520010351220.

Lan-Lan Chang, Kenneth F. Backman, Yu Chih Huang, (2014) "Creative tourism: a preliminary examination of creative tourists' motivation, experience, perceived value and revisit intention", International Journal of Culture, Tourism and Hospitality Research, Vol. 8 Issue: 4, pp.401-419, https://doi.org/10.1108/IJCTHR-042014-0032.

Ljudevit Pranić, Lidija Petrić, Liljana Cetinić, (2012) "Host population perceptions of the social impacts of sport tourism events in transition countries: Evidence from Croatia", International Journal of Event and Festival Management, Vol. 3 Issue: 3, pp.236-256, https://doi.org/10.1108/17582951211262684.

Lovelok, C., Wirtz, Jochen, Lapert, D., \& Munos, A. (2008). Marketing des services, (6 ed.). Paris: Pearson Education.

Luai E. Jraisat, Mamoun N. Akroush, Ruba Jaser Alfaouri, Laila T. Qatu, Dina J. Kurdieh, (2015) "Perceived brand salience and destination brand loyalty from international tourists' perspectives: the case of Dead Sea destination, Jordan", International Journal of Culture, Tourism and Hospitality Research, Vol. 9 Issue: 3, pp.292-315, https://doi.org/10.1108/ IJCTHR-01-2015-0001.

Marcello Risitano, Ilaria Tutore, Annarita Sorrentino, Michele Quintano, (2017) "The influence of tourists' national culture on their behaviors in a sport mega-event", International Journal of Culture, Tourism and Hospitality Research, Vol. 11 Issue: 2, pp.193-210, https://doi.org/10.1108/IJCTHR-07-2015-0077.

Mohammad Reza Jalilvand, Javad Khazaei Pool, Leila Nasrolahi Vosta, Javad Shabani Nafchali, (2014) "The effect of marketing constructs and tourists' satisfaction on loyalty to a sport destination: A structural equation model and analysis", Education, Business and Society: Contemporary Middle Eastern Issues, Vol. 7 Issue: 4 , pp.316-332, https://doi.org/10.1108/EBS-06-2014-0029 .

Mohinder, C.( 2010). The Impact of HRM Practices on Service Quality, Customer Satisfaction and Performance in the Indian Industry, International Journal of Human Resource Management, 21(4): 551-566

Natasa Slak, Matjaz Robinsak, (2005) "Research amongst providers of active sports holidays in Slovenia", Tourism Review, Vol. 60 Issue: 2, pp.27-31, https://doi.org/10.1108/eb058454.

Omar, J,. Bushra ,A,. Ismail ,A,. Qatada,A.(2017). Assessing Factors that Prevent Female Students from Studying Hotel Management: A Case Study of the University of Jordan (Aqaba Branch) „Journal of Management Research, Vol. 9, No. 4, https://doi.org/10.5296/jmr.v9i4.11690

Omar, Alananzeh, Mohammad Al-Badarneh, Ahmad Al-Mkhadmeh \& Omar Jawabreh (2018): Factors influencing MICE tourism stakeholders' decision making: The case of Aqaba in Jordan, Journal of Convention \& Event Tourism, Journal of Convention \& Event Tourism, Volume 19, - Issue 2, https://doi.org/10.1080/15470148.2018.1526152.

Parasuraman, A., Zeithaml, V.A, \& Berry, L.L. (1991). Refinement and reassessment of the SERVQUAL scale. Journal of Retailing, 67(2), 420-450.

Parasuraman, A., Zeithaml, V.A., \& Berry, L.L. (1985). A conceptual model of service quality and its implications for future research. Journal of Marketing, 49, 41-50.

Qusay ,Q., Jawabreh,O.,Bashar ,M., Rami ,M.(2018). Why Arab Societies do not Encourage the Work of Their Members in Hotels?, Modern Applied Science, Vol. 12, No. 11, https://doi.org/10.5539/mas.v12n11p259.

Sarah Roche, Deborah F. Spake, Mathew Joseph, (2013) "A model of sporting event tourism as economic development", Sport, Business and Management: An International Journal, Vol. 3 Issue: 2, pp.147-157, https://doi.org/10.1108/20426781311325078.

Satyendra Singh, Tapas R. Dash, Irina Vashko, (2016) "Tourism, ecotourism and sport tourism: the framework for certification", Marketing Intelligence \& Planning, Vol. 34 Issue: 2, pp.236-255, https:// doi.org/10.1108/MIP09-2014-0180.

Sayyed Mohsen Allameh, Javad Khazaei Pool, Akbar Jaberi, Reza Salehzadeh, Hassan Asadi, (2015) "Factors influencing sport tourists' revisit intentions: The role and effect of destination image, perceived quality, perceived value and satisfaction", Asia Pacific Journal of Marketing and Logistics, Vol. 27 Issue: 2, pp.191207, https://doi.org/10.1108/APJML-12-2013-0159.

Solmaz Filiz Karabag, (2012), Functions and Behaviors of Tourists in Experience Management Process: Case of Three Independent Business Tourists, in Kenneth F. Hyde, Chris Ryan, Arch G. Woodside (ed.) Field Guide to Case Study Research in Tourism, Hospitality and Leisure (Advances in Culture, Tourism and Hospitality Research, Volume 6) Emerald Group Publishing Limited, pp.275 - 296.

Tauseef ,A.,Jawabreh,O., Al Afeef,M., Almomani,A.,(2012), Impact of Customer Relationship Management of Hotel (A Case study Umaid Bhwan), Asian Journal of Finance \& Accounting,4(1), http://dx.doi.org/10.5296/ajfa.v4i1.1362.

Thomas J. Aicher, Kostas Karadakis, Melfy M Eddosary, (2015) "Comparison of sport tourists' and locals' motivation to participate in a running event", International Journal of Event and Festival Management, Vol. 6 Issue: 3, pp.215-234, https://doi.org/10.1108/IJEFM-03-2015-0011. 
Track Dinning, (2017) "Preparing sports graduates for employment: satisfying employers expectations", Higher Education, Skills and Work-Based Learning, Vol. 7 Issue: 4, pp.354-368, https:// doi.org/10.1108/HESWBL02-2017-0017.

Youngjin Hur, Yong Jae Ko, Cathryn L Claussen, (2011) "Acceptance of sports websites: a conceptual model", International Journal of Sports Marketing and Sponsorship, Vol. 12 Issue: 3, pp.13-27, https://doi.org/10.1108/IJSMS-12-03-2011-B003.

Yvette Reisinger, Robert Z. Waryszak, (1994) "Tourists' Perceptions of Service in Shops:: Japanese Tourists in Australia", International Journal of Retail \& Distribution Management, Vol. 22 Issue: 5, pp.20-28, https:// doi.org/10.1108/09590559410067307. 